\title{
石炭利用と環境問題について
}

日本製紙連合会 参与 鈴 木 卓

\section{Utilization of Coal and Environmental Problem}

\author{
Taku Suzuki \\ Japan Paper Association, Vice-chairman, Environment Conservation Committee
}

In Connection with recent energy problems, administrative countermeasures to be taken by authorities concerned with environment conservation are examined. As a report that may be called a tentative plan for a basis of discussion of this matter has been published, I will introduce its essential points to readers in this article.

Coal ocuppies an inportant position as a substitute energy for oil, but, in order to use coal on a large scale, there is many a problem characteristic of coal such as air and water pollution and disposal of cinders, etc.

It is believed that future environmental administration and preparations to receive overseas coal will become key factors if coal is to be utilized according to schedule.

Environment agency is said to be taking enforcement of environmental regulations into account, but we wish that, recognizing fully the importance of energy problem, it will work out appropriate measures enabling environment to be compatible with energy.

\section{1.はじめに}

環境庁は, 昨今のエネルギー問題に関連して, 環境 行政面の対応について模索しているが，そのタタキ台 ともいうべき「エネルギーと環境問題」に関する提言 が公表された。これはエネルギー制約のもとにおける 環境行政の基本的方向と，留意すべき事項について集 約したものであり，(1)環境基準の維持，達成を図るこ と ，(2)自然環境の保全に留意することの基本原則を 改めて強調している。

さらにその後，「石炭利用の拡大に伴う 環境影響と その防止対策に関する分析」と題する環境保全面から 見た「石炭対策要綱」ともいうべきものが発表されて いる。

石炭の需要見通しについては, 昭和 65 年度におい て, 電力が 4,200 万 $\mathrm{t}$, セメントが 2,100 万 $\mathrm{t}$, その 他 1,350 万 $\mathrm{t}$ の合計 6,650 万 $\mathrm{t}$ に達すると予測されて いる。

こうした石炭利用の桩大に伴って生ずる大気污染や
水質污濁，石炭灰の処理，処分など，石炭特有の環境 影響要因を分析し，それに対応した防止技術の現状と 開発動向を集約している。

この検討報告書をらけた環境庁は, 今後, 石炭火力 発電哲の立地や燃料転換に際しての番查指針として運 用する考えのよ5である。

当業界における石炭の消費量は, 昭和 30 年代に 270 万 $\mathrm{t} に$ 達したが, その後は安価な石油に転換されて しまった。それが 54 年来の石油高騰によって石炭だ きを再開する工場が相次ぎ, 56 年 5 月現在では 7 社 9 工場で合計 16 午のボイラーが稼動している。

通産省の調査によれば, 紙パルプ業界における今後 の石炭需要は, 57 年度に 107 万 $\mathrm{t}, 60$ 年度に 218 万 $\mathrm{t}, 65$ 年度に 350 万 $\mathrm{t}$ と見込まれている。

こうした大量の石炭を使用するためには, 多くの制 約要因があり，今後の技術開発と海外炭の受入体制等 が期待される。

環境庁は，規制の強化を検討していると閶くが，エ ネルギー問題の重要性を充分認識して, 環境とエネル 


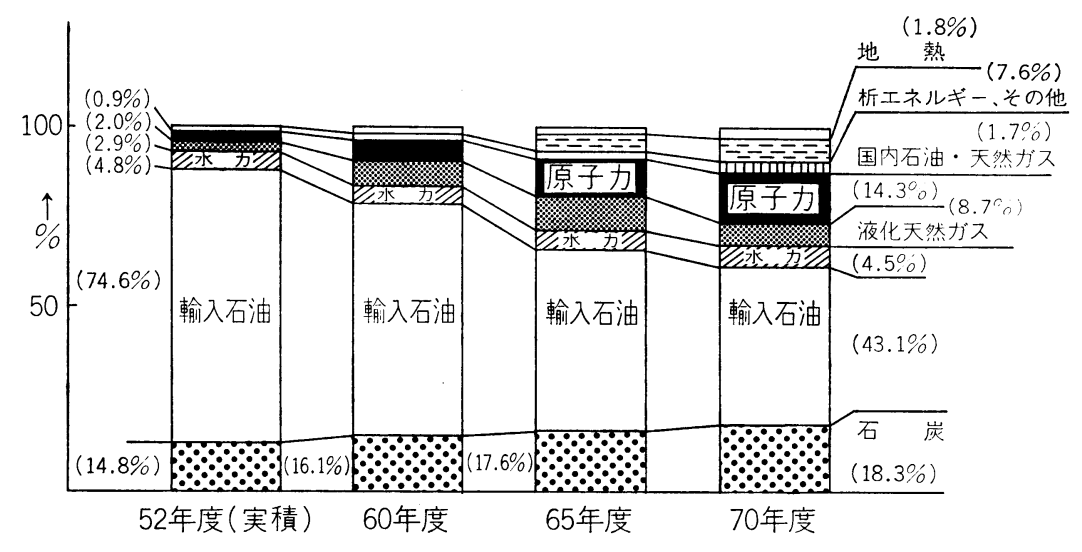

(出典) : 総合エネルギー調查会 (54.8.28) による.

図 1 長期エネルギー需給見通し

ギーが両立できるよう適切な対応を望むものである。

\section{2. 今後のエネルギー需給と石炭利用の見通し}

\section{1 今後のエネルギー需給計画}

わが国の中期的なエネルギー需給及び石炭利用につ いての見通しは，既に示されている通りである（表 1)。なお，電力需給の長期見通しについては省略す る。

\section{2 石炭利用拡大の見通し}

今後の石炭利用の拡大は, 長期エネルギー需給暫定 見通しによると, 昭和 52 年度で $15 \%$ 程度であった供 給比率を，65 年度には $17.6 \% ， 70$ 年度にはに $18.3 \%$ 高めることになるが，これを実数でみると 52 年度の 供給量約 7,800 万 $\mathrm{t}$ を 65 年度に 1 億 6,350 万 $\mathrm{t}, 70$ 年度には 1 億 9,800 万 $\mathrm{t}$ と, 年率 $5 \%$ で増加していく こととされている（図1）。

一方, 国内炭の生産量は, 採炭技術および採炭コス 卜の制約から引続き 2,000 万 $\mathrm{t}$ 程度で横ばいに推移す る見通しが確実なため, 需要增加は海外炭に頼らざる を得ない(表 2)。

海外炭の供給については, 産炭国の港湾設備, 搬出 ルート, 労務者問題等の制約要因が多く, また受入れ 体制についても専用船の建造, 貯炭方式, 廃棄物処理 等の問題が山積している。また, 石炭はハンドリング が困難なために, 海外炭の利用施設は陸揚げ地点の周 辺に集中立地する可能性がある。

こうした基本的な特徵をふまえると, 当面, 石炭利 用の拡大を図る分野は，石炭を大量に使用する大規模 な施設を中核として，コールチェーンを完結し得る業
種, ししくは既に原材料や製品輸送のためのインフラ ストラクチャーを有している業種が中心になる。

これに該当する主な業種としては, 以下のものが挙 げられる。

1) 電気事業 (石炭火力発電所)

2）セメント製造業（セメント焼成炉）

3）鉄鋼業（高炉用の原料炭）

4）紙・パルプ製造業（ボイラー）

ただし，コールセンターや灰処理センター等のイン フラストラクチャーが整備され, かつ, 一般炭の輸入 が自由化されるようになれば, さらに用途は拡大して 中小工場での需要もでてくるものと見られている。

\section{3 業種別, 石炭利用の見通し}

代表的な業種について簡単に触れてみよう。

\subsection{1 電気事業(自家発を除く)}

一般炭利用の大口は電気事業であり, 電力需給の長 期見通しによると, 石炭火力の比率は 53 年度の $5 \%$ から 60 年度は $8 \%, 65$ 年度は $18 \%, 70$ 年度が $27 \%$ に上昇することなる（表 3 ）。

現在, 明らかにされている石炭転換計画によると, 発電所は 4 地点で 8 基, 合計出力は 115 万 $\mathrm{kW}$ とな っている。また, 石炭の混焼率を上げるものは, 3 地 点で 5 基, 合計出力は 85.5 万 $\mathrm{kW}$ となっている。

石炭の利用形態はほとんど微粉炭燃焼であるが，一 部 COM (石炭と石油の混合然料) の使用も考えられ ている。

\subsection{2 セメント製造業}

昭和 53 年に 46 万 $\mathrm{t}$ であった石炭使用量は, 54 年 に 156 万 $\mathrm{t}$ に達し， 55 年には 600 万 $\mathrm{t}$ を超えている。 
表 1 長期エネルギー需給暫定見通し

（昭和 54 年 8 月 31 日総合エネルギー調查会需給部会）

\begin{tabular}{|c|c|c|c|c|c|c|c|c|}
\hline 項目 $\quad$ 年度 & 52 年度（実 & 夷績） & 年 & 度 & 65 & 度 & 70 & 度 \\
\hline $\begin{array}{l}\text { 省エネルギー前の需要 } \\
\text { 省 エ ル ギー 率 } \\
\text { 省エネルギー後の需要 }\end{array}$ & 4.12 億 & & $\begin{array}{l}6.62 \mathrm{k} l \\
12.1 \% \\
5.82 \text { 億 }\end{array}$ & & $\begin{array}{l}8.22 \text { 億 } \\
14.8 \% \\
7.00 \text { 億 }\end{array}$ & & $\begin{array}{l}9.73 \text { 億 } \\
17.1 \% \\
8.07 \text { 億 }\end{array}$ & \\
\hline エネルギー別 区分 & 数 & 構成比 & 数 & \begin{tabular}{|l} 
構成比 \\
$(\%)$
\end{tabular} & 実 & $\left|\begin{array}{|c|}\mid \text { 構成比 } \\
(\%)\end{array}\right|$ & 数 & \begin{tabular}{|c|} 
構成比 \\
$(\%)$
\end{tabular} \\
\hline 水力 $\left\{\begin{array}{l}\text { 一般水力 } \\
\text { 担 }\end{array}\right.$ & $\begin{array}{r}1,810 \text { 万 } \mathrm{kW} \\
805 \text { 万 } \mathrm{kW}\end{array}$ & 4.8 & 2,200 万 $\mathrm{kW}$ & 4.7 & 2,600 万 $\mathrm{kW}$ & 4.6 & 3,000 万 $\mathrm{kW}$ & 4.6 \\
\hline 地 & 15 万 $\mathrm{k} l$ & 0.0 & 220 万 $\mathrm{k} l$ & 0.4 & 730 万 $\mathrm{k} l$ & 1.0 & 1,420 万 $\mathrm{k} l$ & 1.8 \\
\hline 国内石油 ・ 天然ガス & 379万 $\mathrm{k} l$ & 0.9 & 800 万 $\mathrm{k} l$ & 1.4 & 950 万 $\mathrm{k} l$ & 1.4 & 1,400 万 $\mathrm{k} l$ & 1.7 \\
\hline 国 内 石 炭 & 1,972 万 $\mathrm{t}$ & 3.2 & 2,000 万 $\mathrm{t}$ & 2.5 & 2,000 万 $\mathrm{t}$ & 2.0 & 2,000 万 $\mathrm{t}$ & 1.8 \\
\hline 子 & 800 万 kW & 2.0 & 3,000 万 $\mathrm{kW}$ & 6.7 & 5,300 万 $\mathrm{kW}$ & 10.9 & 7,800 万 $\mathrm{kW}$ & 14.3 \\
\hline $\begin{aligned} \text { 海 外 石 炭 } \\
\\
\text { 〔らち一般炭〕 }\end{aligned}$ & $\begin{array}{l}5,829 \text { 万 } t \\
{[95 \text { 万 } t]}\end{array}$ & 11.6 & $\begin{array}{l}10,100 \text { 万 } \mathrm{t} \\
{[2,200 \text { 万 } \mathrm{t}]}\end{array}$ & 13.6 & $\begin{array}{l}14,350 \text { 万 } \mathrm{t} \\
{[5,350 \text { 万 } \mathrm{t}]}\end{array}$ & 15.6 & $\begin{array}{l}17,800 \text { 万 } t \\
{[8,050 \text { 万 } t]}\end{array}$ & 16.5 \\
\hline N $\quad$ G & 839万 t & 2.9 & 2,900 万 $\mathrm{t}$ & 7.2 & 4,500 万 $\mathrm{t}$ & 9.0 & 5,000 万 $\mathrm{t}$ & 8.7 \\
\hline $\begin{array}{l}\text { 新燃料油, 新エネルギ } \\
\text { その他 }\end{array}$ & & 0.1 & 520 万 $\mathrm{k} l$ & 0.9 & 3,850 万 $\mathrm{k} l$ & 5.5 & 6,100 万 $\mathrm{k} l$ & 7.6 \\
\hline 小 計 & 1.05億 $\mathrm{k} l$ & 25.5 & 2.16 億 $\mathrm{k} l$ & 37.1 & 3.50 億 $\mathrm{k} l$ & 50.0 & 4.59 億 $\mathrm{k} l$ & 56.9 \\
\hline $\begin{array}{r}\text { 輸 入 石 油 } \\
\text { [らち LPG }\end{array}$ & $\begin{array}{l}3.07 \text { 億 } \mathrm{k} l \\
\text { 〔739万 } \mathrm{t} \text { 〕 }\end{array}$ & 74.5 & $\begin{array}{l}3.66 \text { 億 } \mathrm{k} l \\
{[2,000 \text { 万 } \mathrm{t} 〕}\end{array}$ & 62.9 & $\begin{array}{r}3.66 \text { 億 } \mathrm{k} l \\
(3.50 \text { 億 } \mathrm{k} l \text { ) } \\
{[2,600 \text { 万 } \mathrm{t}}\end{array}$ & 50.0 & $\begin{array}{r}3.66 \text { 億 } \mathrm{k} l \\
(3.48 \text { 億 } \mathrm{k} l) \\
{[3,300 \text { 万 } \mathrm{t}]}\end{array}$ & 43.1 \\
\hline 供 給 合 計 & 4.12億 $\mathrm{k} l$ & 100.0 & 5.82 億 $\mathrm{k} l$ & 100.0 & $\begin{array}{c}\text { 7.16億 } \mathrm{k} l \\
(7.00 \text { 億 } \mathrm{k} l)\end{array}$ & 100.0 & $\begin{array}{l}8.25 \text { 億 } \mathrm{k} l \\
(8.07 \text { 億 } \mathrm{k} l\end{array}$ & 100.0 \\
\hline 供 給 一 需 要 & - & & - & & 1,600 万 $\mathrm{k} l$ & $(-)$ & 1,800 万 $\mathrm{k} l$ & $(-)$ \\
\hline & & & 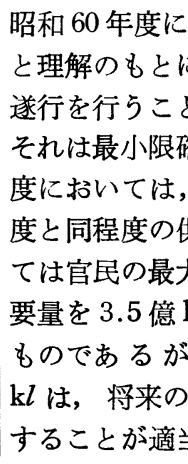 & 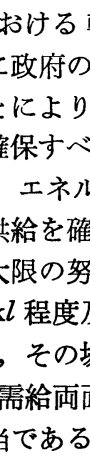 & 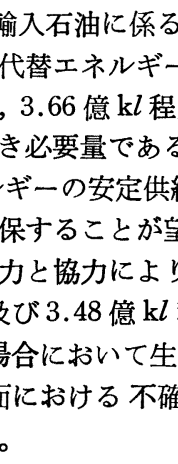 & 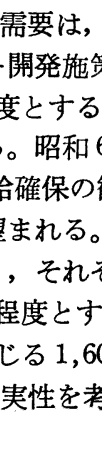 & $\begin{array}{l}\text { 民間の最大限 } \\
\text { 策等の重点かつ } \\
\text { ことが可能でむ } \\
65 \text { 年度及び昭和 } \\
\text { 観点から, 昭和 } \\
\text { なお, 両年度 } \\
\text { ぞれ輸入石油に } \\
\text { ることを目標 } \\
00 \text { 万 } l \text { 及び } 1 \\
\text { 虑し, 供給の }\end{array}$ & 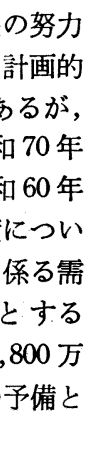 \\
\hline
\end{tabular}

（注） 1.この見通しは，民間の最大限の努力と理解のもとに政府の代替エネルギー開発施策等の重点的かつ 計画的遂行を前提とした場合のエネルギ一需給見通しを示したものである。

2. 石油換算は $9,400 \mathrm{kcal} / l$ による。 また，省エネルギー率は，昭和 48 年度を基準としている。

3. 地熱の 5 , 地熱発電は, 52 年度 8 万 $\mathrm{kW}, 60$ 年度 100 万 $\mathrm{kW}, 65$ 年度 350 万 $\mathrm{kW}, 70$ 年度 700 万 $\mathrm{kW}$ である。

4. 石炭には, 石炭・石油混合燃料，低カロリーガス化等に利用される石炭を含む。

5. 新燃料油, 新エネルギー, その他には, 石炭液化油, オイルサンド油, オイルシェール油, アルコ 一ル燃料，太陽エネルギー，薪炭等を含む。

6. 石油備蓄については,この需給見通し上は考慮していない。

7. 昭和 65 年及び 70 年度の輸入石油の供給合計に対する構成比は，（）内の輸入石油量に基づいて 算出したものである。

8. サンシャイン計画によるエネルギー供給量は, 昭和 65 年度約 $5 \%$, 昭和 70 年度約 $7 \%$ である。

9. 各欄の合計は四捨五入の関係で合計欄の数字に一致しないことがある。

10. この見通しの各数值については, 今後, 各種政策等の検討を加えることにより, 異動することがある。 
表 2 石炭の生産 量

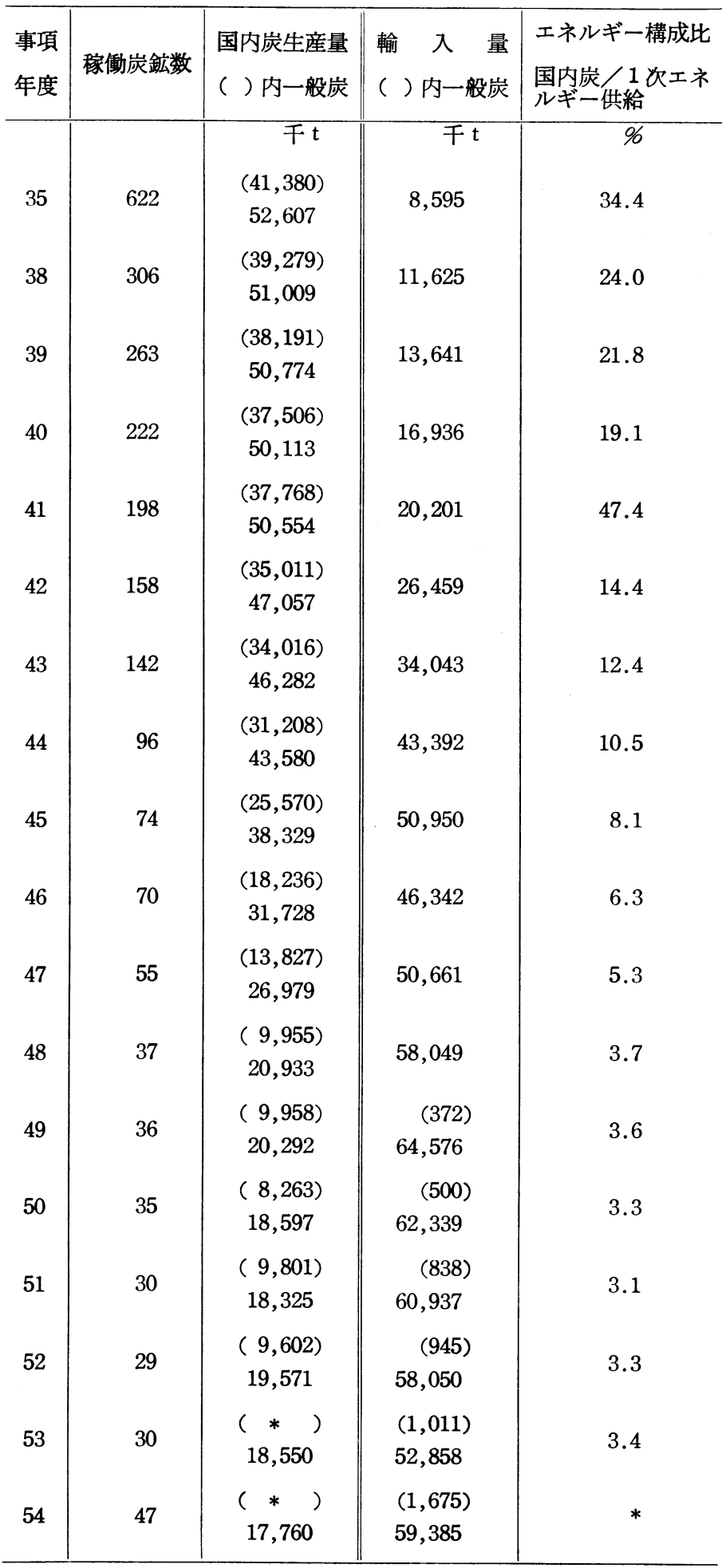

（注 1）（出典）エネルギー統計（生 産量, 常用実働労 働者数, 能率) エネルギー統計年報 （稼働炭鉱数，輸 入量)

（注 2）一般炭の輸入は 49 年度から （注 3）* 未集計 
表 3 火力発電電力量の推移

\begin{tabular}{|c|c|c|c|c|c|c|c|c|}
\hline & & 電 & 電 力 & 量 & \multicolumn{3}{|l|}{ （億kWh） } \\
\hline & 53 年 度 & $\begin{array}{l}\text { 構成比 } \\
(\%) \text { ) }\end{array}$ & 60 年 度 & $\begin{array}{l}\text { 構成比 } \\
(\%)\end{array}$ & 65 年 度 & $\begin{array}{l}\text { 構成比 } \\
(\%) \text { ) }\end{array}$ & 70 年 度 & $\begin{array}{c}\text { 構成比 } \\
(\%)\end{array}$ \\
\hline 石 炭 & 176 & 4.7 & 385 & 7.7 & 995 & 18.2 & 1,565 & 27.3 \\
\hline $\mathrm{L} N \mathrm{~N}$ & $\begin{array}{l}(162) \\
496\end{array}$ & $\begin{array}{l}(4.4) \\
13.4\end{array}$ & $\begin{array}{r}(160) \\
1,190\end{array}$ & $\begin{array}{l}(3.2) \\
23.9\end{array}$ & $\begin{array}{c}(160) \\
1,795\end{array}$ & $\begin{array}{l}(2.9) \\
32.9\end{array}$ & $\begin{array}{r}(160) \\
1,950\end{array}$ & $\begin{array}{l}(2.8) \\
34.0\end{array}$ \\
\hline 地 熱 & 5 & 0.1 & 40 & 0.8 & 165 & 3.0 & 345 & 6.0 \\
\hline$L P G$ & 18 & 0.5 & 210 & 4.2 & 220 & 4.0 & 220 & 3.8 \\
\hline 石 油 & 2,834 & 76.8 & 3,000 & 60.2 & 2,125 & 38.9 & 1,495 & 26.1 \\
\hline 合 計 & 3,691 & 100 & 4,985 & 100 & 5,460 & 100 & 5,735 & 100 \\
\hline
\end{tabular}

（注） 全発電電力量の $L N G$ 欄（）内は，高炉ガス等による発電電力量で外数である。ただし合計 には含む。

（出典） 電気事業番議会需給部会「長期電力需給」より作成。

なお, 57 年には 800 万 $\mathrm{t}, 60$ 年には 1,000 万 $\mathrm{t}$ に達 すると見込まれている。この時点における転換率は 80\%になる。

このようにセメント業界で石炭転換が急速に行われ るのは, C重油の值上りのほか焼成焒自体の改造を必 要としない点, さらには石炭灰そのものが原料の一部 となる等の特徵をもっていることに大きな理由がある と考えられている。

\subsection{3 鉄 鋼 業}

鉄鋼業界で使用されるのは原料炭であり, 石炭転換 の対象施設は高炉である。オイルレス化については, 大手鉄鋼メーカーを中心に進められており，かなりの 実績を挙げている製鉄所む見らけられる。また，微粉炭 吹込みや COM 吹込み方式についても検討されている が，コスト面と安全面における技術開発が必要である。

\subsection{4 紙・パルプ製造業}

昭和 35 年度には 268 万 $\mathrm{t}$ の石炭を使用したが， 53 年度では 4.3 万 $\mathrm{t}$ と急减しており, ほとんどの工場は 重油に変ってきている。53 年度における重油使用量 は 730 万 $\mathrm{k} l$ であった。

紙パルプ業界における石炭使用の動向は表 4 の通り で, 54 年の下半期から再び増加し始めている。これは 過去に使用していた石炭ボイラーを再び稼動させたも のである。

今後の石炭利用と転換計画は, 石炭ボイラーの再稼
表 4 最近における石炭使用量推移

(単位： $t$ )

\begin{tabular}{c|r|rr}
\hline 月 & 53 年 & 54 & 年（前年比 \%) \\
\hline 1 & 4,289 & 3,012 & $(70.2)$ \\
2 & 3,625 & 3,626 & $(100.0)$ \\
3 & 4,050 & 3,132 & $(77.3)$ \\
4 & 4,205 & 2,932 & $(69.7)$ \\
5 & 3,639 & 2,543 & $(69.9)$ \\
6 & 3,414 & 1,991 & $(58.3)$ \\
7 & 3,611 & 5,729 & $(158.6)$ \\
8 & 3,247 & 12,555 & $(386.7)$ \\
9 & 2,864 & 8,898 & $(310.7)$ \\
10 & 3,238 & 11,373 & $(351.2)$ \\
11 & 3,259 & 13,931 & $(427.5)$ \\
12 & 3,354 & & \\
\hline 計 & 42,795 & & \\
\hline
\end{tabular}

（資料）「紙・パルプ統計月報」通産省（製紙連 合会資料による) 
動と再転換のほか, 新設についても見込まれているが, これについては具体的に後述する。

60 年度までの転換・新設計画が順調に進めば, 140 万 $\mathrm{t}$ 程度の石炭消費量に達するものと推定されている。

一般炭の利用見通しをまとめると, 表 5 の通りであ る。

\section{4 紙・パルプ業界における石炭転換計画}

石炭利用に関する動向については上述の通りである が, 最近における石炭消費の推移と具体的な転換計画 について紹介する。

当業界における石炭消費量は, 54 年の 8.6 万 $\mathrm{t}$ か ら 55 年には 23.8 万 $\mathrm{t}$ 一約 3 倍に増大している(表 6 )。 昭和 30 年代の 石炭全盛期には 270 万 $\mathrm{t}$ （36 年）に も達したが，その後は安価な不油に転換された結果, 53 年時点においては日光製紙のみとなっていた。そ れが 54 年来の石油高騰によって石炭だきを再開する 工場が相次ぎ, 56 年 5 月現在では 7 社 9 工場で 合計 16 缶の石炭だきボイラーが稼動している。

これら石炭転換はすべて旧ボイラーの再稼動, 再転 換によるものであり, 今後 $1 \sim 2$ 年もこうした形態が 主流となるであろう。これはハンドリングや環境保全 対策等の石炭によるデメリットのほか, 灰の処理・処 分, 輸入炭の不安定さが起因していると考えられる。 特に石炭灰の処理・処分は, 捨て場の確保難から石炭
転換に当たって，最大の制約条件となっている。

今後の石炭転換は, 再稼動と再転換によるもののほ か, 57 年度以降に 蒸発量 $250 \sim 350 \mathrm{t} /$ 時の 大型ボイラ 一の新設も計画されている（表 7 )。

通産省の調査によると, 当業界における石炭の需要 は, 56 年度に 80 万 $\mathrm{t}, 57$ 年度は 107 万 $\mathrm{t}, 58$ 年度 が 197 万 $\mathrm{t}, 60$ 年度が 218 万 $\mathrm{t}, 65$ 年度には 350 万 $\mathrm{t}$ と見込まれている。しかし，こうした大量の石炭を 使用するためには多くの制約要因があり，今後の技術 開発や海外炭の受入体制の整備等が期待される。

3. エネルギーと環境問題についての提言 (エネ ギーと環境問題摡談会)

\section{一石炭の利用に伴って——}

\section{1 まえがき}

去る 3 月に「エネルギーと環境問題想談会」が提言 した内容をみると, (1)環境基準の維持・達成を図るこ とと, (2)自然環境の保全に留意すること, といら基本 原則を改めて強調している。

今回の提言は, 当面の基本的な考え方をまとめたも のであり, 環境保全の面から見て望ましいエネルギー 構造のあり方，エネルギーの利用形態と望ましい体制， 地城別にみたエネルギー需給と環境保全のあり方など については触れていない。

表 5 一般炭需給見通し

(単位 : 万 $\mathrm{t}$ )

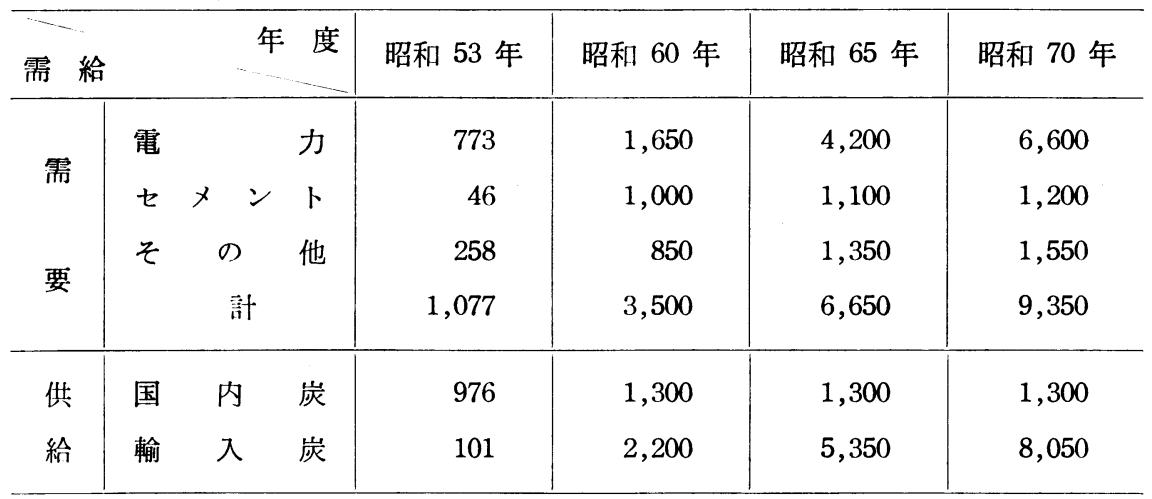

注）1. 将来の国内炭のうち一般炭の生産量を 1,300 万 $\mathrm{t}$ とした。

2. 電気事業の石炭転換については, 予想以上に早いことから, 電気事業審議会報 告の最大值を使用した。

石炭の導入については, 環境政策面からの留意事項 として，(1)環境基準の維持・達成に支障がないか，(2) 使用する石炭の質に問題ないか, (3)石炭灰の処理対策
は妥当かという 3 点から, その是非を判断すべきであ るとしている。また, 立地面からの要請としては, (1) 基準を達成してない地城での新増設は好ましくない, 
表 6 最近における石炭消費量推移

\begin{tabular}{|c|c|c|c|c|c|c|}
\hline & \multicolumn{2}{|c|}{ 昭和 54 年 } & \multirow{2}{*}{$\frac{55}{\begin{array}{c}\text { 消費量 } \\
(\mathrm{t})\end{array}}$} & \multirow{2}{*}{$\begin{array}{l}\text { 年 } \\
\begin{array}{c}\text { 前年比 } \\
(\%)\end{array}\end{array}$} & \multirow{2}{*}{$\frac{56}{\begin{array}{c}\text { 消費量 } \\
(\mathrm{t})\end{array}}$} & \multirow{2}{*}{$\begin{array}{l}\text { 年 } \\
\begin{array}{c}\text { 前年比 } \\
(\%)\end{array}\end{array}$} \\
\hline & $\begin{array}{c}\text { 消費量 } \\
(\mathrm{t})\end{array}$ & $\begin{array}{c}\text { 前年比 } \\
(\%)\end{array}$ & & & & \\
\hline 1月 & 3,012 & $(70.2)$ & 20,863 & $(692.7)$ & 36,863 & (176.7) \\
\hline 2 & 3,626 & $(100.0)$ & 17,273 & $(476.4)$ & 33,687 & $(195.0)$ \\
\hline 3 & 3,132 & ( 77.3$)$ & 20,266 & $(647.1)$ & 34.740 & $(171.4)$ \\
\hline 4 & 2,932 & ( 69.7$)$ & 19,646 & $(670,1)$ & 37,576 & $(191.3)$ \\
\hline 5 & 2,543 & ( 69.9$)$ & 16,301 & $(641.0)$ & & \\
\hline 6 & 1,991 & ( 58.3) & 19,337 & $(971.2)$ & & \\
\hline 7 & 5,729 & $(158,6)$ & 17,237 & $(300.9)$ & & \\
\hline 8 & 12,555 & $(386.7)$ & 16,737 & $(133.3)$ & & \\
\hline 9 & 8,898 & $(310.7)$ & 11,214 & $(126.0)$ & & \\
\hline 10 & 11,373 & $(351.2)$ & 19,735 & $(173.5)$ & & \\
\hline 11 & 13,931 & $(427.5)$ & 27,397 & $(196.7)$ & & \\
\hline 12 & 16,050 & $(478.5)$ & 32,339 & $(201.5)$ & & \\
\hline $1 \sim 12$ 計 & 85,772 & $(200.4)$ & 238.345 & $(277.9)$ & & \\
\hline
\end{tabular}

（資料）「紙・パルプ統計月報」

(2)頼戸内海地域では石炭灰の内陸処理が困難な場合は, 新増設を避けるべきである，(3)国立公園等の重要な地 域での開発は避けること等が提言されている。

石炭の利用について, これから環境質を守りながら 創造するために必要なコストは, 物品の生産コストに 組み入れて消費者に負担してもらうことも，やむを得 ないと指摘している。

なお，環境庁は規制の強化を検討していると聞くが， エネルギー問題の重要性を充分認識して, 環境とエネ ルギーが両立できるよう調整することを期待している。

\section{2 提言に当たっての基本的考え方}

\subsection{1 エネルギー政策と環境政策の関係}

人の生命, 健康は何物にも代え難いものであり, い かなるエネルギー事情であっても, 人の生命, 健康を 脅かす環境污染が発生するような事態は許されない。

一方, エネルギー情勢は石油をめぐって不安定かっ 深刻な样相を呈しており, 今後, 石炭等の代替エネル ギーを開発・導入すべきことは避けられない。

しかし，いずれにしてもエネルギーか環境かという 単純な二者択一的な発想では, この問題の解決策は見 い出せない。エネルギー政策も環境政策も, ともに国 民の快適な生活を実現するための手段であり, 重要な
ことは快適な国民生活を実現するために両政策をいか に両立させるかということである。

\subsection{2 省エネ型社会経済構造}

エネルギーを大量に消費すれば環境污染の可能性が 増大することは明らかであり，また $\mathrm{CO}_{2}$ の増加によ る気候変動の問題も起りかねない。従って, 将来を展 望した場合, エネルギーと環境の両立を図りながら快 適な国民生活の達成を図るためには, 省エネ型の社会 経済構造へ転換していくことが必要である。

民生部門, 運輸部門における省エネ化の努力を更に 進めることが求められる。また, エネルギー消費の面 でウエイトの大きい産業部門については, 今後とも省 エネ投資に力を入れるほか, 産業構造の転換を進める ことが必要であると指摘されている。

\subsection{3 疅境利用のコスト}

環境もエネルギーも同様に有限で貴重な資源である。 従って, 環境を利用するためには, それ相当のコスト が必要となる。企業サイドとしては, PPP (污染者負 担の原則）からも, 公害防除費用は物品の生産に当た り当然組み込むべきコストであることを認識し，それ が最小となるような合理化の努力を行らとともに, 消 費者においても快適な生活を確保するためには, プラ 
表 7 紙・パルプ業界における石炭転換計画

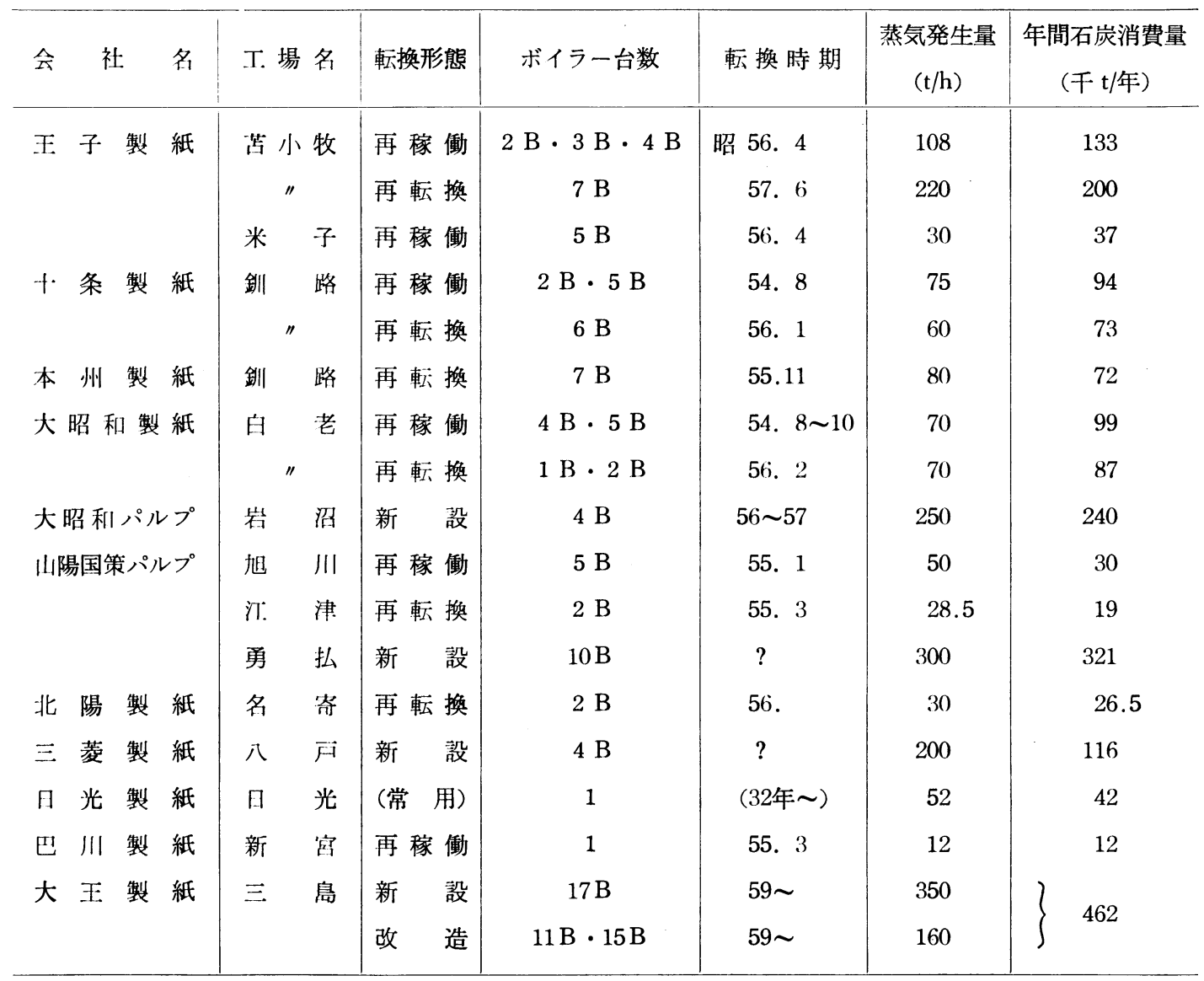

（注） 日本製紙連合会調べによる。

イスメカニズムによって，負担増もやむを得ないこと を理解する必要があるとしている。

\section{3 石炭利用に伴って配虑すべき環境保全}

\subsection{1 石炭の開発利用に伴う環境問題（石炭火力} の例)

1） $\mathrm{SO}_{\mathbf{x}}, \mathrm{NO}_{\mathbf{x}}$ の排出量が増大した場合に，それか ら二次的に生成する硫酸塩, 硝酸塩の問題や，これら によって遠隔地においても発生する酸性雨による生態 系への影響について調査研究を行うことが必要である。

2）石炭には重金属など，多くの微量成分が含まれ ており，燃焼に伴って大気中にある程度放出される。 そのほか, 燃烧に伴って生成される多環芳香族炭化水 素やハロゲンなどの放出があることも指摘されてい る。

3）水質関係; 湿式脱硫排 水中のフッ素, 塩素, $\mathrm{COD}$ 等が指摘されているほか, 洗浄水, 粉じんの飛 散防止用散水等が使用される段階ごとに問題となる可
能性がある。

4）石炭灰; 石炭には平均 $20 \%$ 程度の灰分が含ま れ，これが燃焼後に石炭灰として残るため，その処分 が問題となる。わが国では石炭灰を一部有効利用して いるものの, 大部分は埋立て処分されているが，埋立 地の確保難から今後は海面埋立てに向から傾向があり， 土地改変に伴う環境への影響, 海域環境への影響, 浸 出水等について充分配慮することが必要である。

\subsection{2 当面の措置についての考え方}

\subsubsection{1 今後の課題}

1）適正立地の推進；石炭の大規模な利用に当たっ ては, 受入れ港湾の整備, 広大な用地の確保および石 炭灰の処理が必要となるが，環境の改変によって環境 保全に支障を生じないよう立地点の選定段階から環境 影響に充分配慮することが必要である。

2）污染物質の解明; 大気中に放出される污染物質 の拡散等については未解明の点もあり, また石炭中の 
表 8 石炭, 石油火力発電所の環境関連諸元比較

\begin{tabular}{|c|c|c|c|}
\hline 大 項 目 & 項 & 石 炭 火力 & 石 油火力 \\
\hline $\begin{array}{l}\text { 所 要 敷 地面 積 等 } \\
(100 \text { 万 } \mathrm{kW} \times 2 \text { 基） }\end{array}$ & 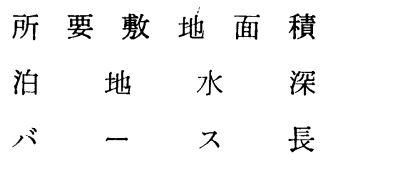 & $\begin{array}{r}90 \text { ha } \\
14 \sim 19 \mathrm{~m} \\
750 \mathrm{~m}\end{array}$ & $\begin{array}{c}60 \mathrm{ha} \\
7.5 \mathrm{~m} \\
\text { (ドルフィンで可) }\end{array}$ \\
\hline $\begin{array}{l}\text { 燃 料 使 用 量 } \\
\text { (100万 } \mathrm{kW} \text { ユニット) }\end{array}$ & $\begin{array}{l}\text { 年間使用量（利用率 70\%） } \\
1 \text { 時間最大使用量（最大負荷時） }\end{array}$ & $\begin{array}{r}230 \text { 万 } \mathrm{t} \\
370 \mathrm{t}\end{array}$ & $\begin{array}{l}130 \text { 万 } \mathrm{t} \\
210 \mathrm{t}\end{array}$ \\
\hline 燃 料 性 状 & 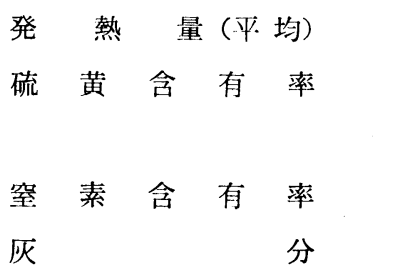 & $\begin{array}{l}\quad 6,200 \mathrm{kcal} / \mathrm{kg} \\
0.3 \sim 1.6 \% \\
1.2 \sim 1.8 \% \\
15 \sim 20 \%\end{array}$ & $\begin{array}{c}10,000 \mathrm{kcal} / \mathrm{kg} \\
\text { (原油) } 0.14 \% \\
\text { (重油) } 0.87 \% \\
0.05 \sim 0.5 \% \\
0.01 \%\end{array}$ \\
\hline $\begin{array}{l}\text { 排 出 ガ ス 量 等 } \\
(100 \text { 万 } \mathrm{kW} \text { ユニット) }\end{array}$ & $\begin{array}{l}\text { 排出ガス量（最大負荷時乾ガス） } \\
\mathrm{SO}_{\mathbf{x}} \text { 発生量（最大負荷時） } \\
\mathrm{SO}_{\mathbf{x}} \text { 発 生 濃 度 } \\
\mathrm{NO}_{\mathbf{x}} \text { 発生量（最大負荷時） } \\
\mathrm{NO}_{\mathbf{x}} \text { 発 生 濃 度 } \\
\text { ばいじん発生量（最大負荷時） } \\
\text { " 発 生 濃 度 }\end{array}$ & $\begin{array}{r}310 \text { 万 } \mathrm{Nm}^{3} / \mathrm{h} \\
780 \sim 4,100 \mathrm{Nm}^{3} / \mathrm{h} \\
250 \sim 1,300 \mathrm{ppm} \\
\\
530 \sim 930 \mathrm{Nm}^{3} / \mathrm{h} \\
170 \sim 300 \mathrm{ppm} \\
6.2 \sim 7.8 \mathrm{t} / \mathrm{h} \\
20 \sim 25 \mathrm{~g} / \mathrm{Nm}^{3}\end{array}$ & $\begin{array}{cc} & 260 \text { 万 } \mathrm{Nm}^{3} / \mathrm{h} \\
\text { (原油) } & 200 \mathrm{Nm}^{3} / \mathrm{h} \\
\text { (重油) } & 1,300 \mathrm{Nm}^{3} / \mathrm{h} \\
\text { (原油) } & 80 \mathrm{ppm} \\
\text { (重油) } & 500 \mathrm{ppm} \\
& \sim 340 \mathrm{Nm}^{3} / \mathrm{h} \\
& \sim 130 \mathrm{ppm} \\
& 260 \mathrm{~kg} / \mathrm{h} \\
& \sim 0.1 \mathrm{~g} / \mathrm{Nm}^{3}\end{array}$ \\
\hline
\end{tabular}

（注）（1）石炭火力については直送方式で海外炭を用いる最近の大型火力発電所の計画例に基うきき，また 石油火力については, 昭和 54 年度の 9 電力の燃料使用実績等を参考に試算したものである。

(2) $\mathrm{SO}_{\mathbf{x}}$, ばいじんの発生量は, 排ガスの処理効果を含まない。 $\mathrm{NO}_{\mathbf{x}}$ 発生量は燃焼改善のみを含 み，排ガス処理効果を含をない。

（3）石炭の使用形態は微粉炭然焼とした。

微量成分については炭質によって大きな差異があるた め, 今後わが国に供給される石炭について調查を進め る必要がある。

3）排出基準の見直し等; 石炭需給拡大の動向に伴 う業種別, 規模別の利用分野, 技術開発の程度等の変 化に着目し，必要に応じて基準の強化，見直しについ て検討し，適切な対応をおこなうことが求められよう。 4）石炭灰の処理；今後かなり大量の石炭灰が継続 的に発生するので，環境保全の見地から必要な対策を 講ずべきである。

\section{4 まとめ}

エネルギー政策と環境政策とは両立させる必要があ り，また，それ以外にわが国の進むべき道のないこと が明らかとなった。この両立については, $\mathrm{SO}_{\mathrm{x}}$ 対策, 電源立地政策の例にみられる通り, かなりの成果を挙 げてきた。しかし，昨今エネルギー事情の急変によっ て新たなエネルギー政策の展開がなされ，代替エネル ギーの使用拡大に向けて施策が進められている。従っ て, 環境政策の立場からは, このような事態に立ち遅 れることのないよう適確な対応が必要となる。 
表 9 大気污染に関する主要な問題の分類

\begin{tabular}{|c|c|c|c|c|c|c|}
\hline \multirow{3}{*}{ 分類 } & \multirow{3}{*}{ 污染原因物質 } & \multicolumn{4}{|c|}{ 石炭利用プロセス } & \multirow{3}{*}{ 備 } \\
\hline & & \multirow{2}{*}{ 輸送・貯蔵 } & \multicolumn{2}{|c|}{ 燃 焼 } & \multirow{2}{*}{ 灰処理 } & \\
\hline & & & ボイラー & $\begin{array}{l}\text { セメント } \\
\text { キルシ }\end{array}$ & & \\
\hline \multirow{3}{*}{ I } & $\mathrm{SO}_{\mathrm{x}}$ & & (2) & & & 石油利用に比べ発生量が \\
\hline & $\mathrm{NO}_{\mathbf{x}}$ & & (O) & (2) & & 増大する可能性が大きい \\
\hline & ば & & (O) & & & 項目 \\
\hline II & 粉 じん（炭じん） & (2) & & & (2) & 石炭利用に特徽的項目 \\
\hline \multirow{4}{*}{ III } & \multirow{3}{*}{$\begin{array}{l}\text { 微量重金属（水銀等） } \\
\text { 多環芳香族炭化水素 } \\
\text { ハロゲン (フッ素, 塩素) }\end{array}$} & & (O) & (O) & & 石炭中含有率が高い項目 \\
\hline & & & () & ( ) & & 発がん性物質として \\
\hline & & & (ㅇ) & (0) & & 石炭中含有率が高い項目 \\
\hline & 二酸 化菠 素 & & $\bigcirc$ & 0 & & 化石燃料に共通の項目 \\
\hline IV & 硫 酸 塩, 硝酸 塩 & & O & 0 & & 分類 I との関連性大 \\
\hline
\end{tabular}

（注）@：石炭利用に伴って生ずる大気污染に関する問題で, 本検討会で特に検討対象とするもの。

○：石炭利用に伴って生ずる大気污染に関する問題であるが，本検討会で詳細に立ち入って検討す ることを差し㨬えたもの。

以上のような観点から「エネルギーと環境」の問題 について, 基本的な考え方と必要な施策について提言 がなされたものである。

環境庁は, この提言を受けてエネルギーと環境問題 についての基本方針を取りまとめることになっている。

\section{4. 石炭利用に伴う環境問題}

\section{1 環境影警の概要}

石炭の利用に伴う環境問題としては, 大気污染及び 灰の処理が主要なものである。すなわち, $\mathrm{SO}_{\mathbf{x}}, \mathrm{NO}_{\mathbf{x}}$, ばいじん等の発生は, 石油の場合に比べてかなり多い ことのほか, 石炭灰は大変な厄介ものである。

これ以外にも, 眝炭場の排水や排煙脱硫装置から出 る排水等による水質污濁問題がある。

これらの事情を比較するため, 100 万 $\mathrm{kW}$ 火力発電 所を例にとって, 石炭の場合と石油を使用する場合で の環境関連の諸元を比較したのが表 8 である。

\section{2 大気污染に関する問題}

石炭の利用に伴って発生する大気污染の問題を, 石 炭利用のプロセス別に整理したのが表 9 である。

石炭火力発電所の $\mathrm{SO}_{\mathbf{x}}, \mathrm{NO}_{\mathbf{x}}$ 及びばいじんの発生 湿度ならびに脱硫装置, 脱硝装置, 除じん装置による
排ガス処理後の濃度については, 表 10 のように 計画 あれている。

\section{3 石炭ボイラーの問題点}

\subsection{1 排出濃度と排出量}

\subsubsection{1 硫黄酸化物 $\left(\mathrm{SO}_{\mathbf{x}}\right)$}

現在, 9 電力会社で使用している燃料の硫黄分は, 重油が $0.87 \%$, 原油で $0.14 \%$, 石炭 (国内炭) で $0.56 \%$ となっている。

排煙脱硫装置（効率 90\%）で処理すれば, 表 11 に 例示した通り，仕上り硫黄分は重油換算で約 $0.2 \%$ に なり，排煙脱硫後の全燃料平均值（火力発電所）とほ ぼ同じ值となる。

\subsubsection{2 窒素酸化物 $\left(\mathrm{NO}_{\mathrm{x}}\right)$}

石油火力の場合は, 燃焼改善によって排出 $\mathrm{NO}_{\mathbf{x}}$ を 110 120 ppm としているが, 石炭火力の場合には 170 〜180 ppm まで低減できるとされているものの, かな りの問題が残されているといえよう。

石炭火力の $\mathrm{NO}_{\mathbf{x}}$ 排出量を石油火力と同一レベルに するためには, 発生浱度が 170 180 ppm の場合で排 出ガス量の $50 \%$ を, また排出浱度 $300 \mathrm{ppm}$ の場合に は 80\% 程度を脱硝処理（脱硝効率 80\%）する必要が ある。 
表 10 最近の海外炭を主力とする石炭専焼火力発電所のばい煙排出計画例

\begin{tabular}{|c|c|c|c|}
\hline & 発生濃度 & 処 理 後 濃 度 & 処 理 技 術 \\
\hline 硫黄酸化物 (S 分 $1.2 \%$ ) & $1,000 \mathrm{ppm}$ & $100 \mathrm{ppm}$ & 湿式脱硫 $(\eta=90 \%)$ \\
\hline 窒素酸化物 (N分 1.8\%) & $170 \sim 300 \mathrm{ppm}$ & $60 \mathrm{ppm}$ & 乾式脱硝 $(\eta=80 \%)$ \\
\hline ばいじん(灰分 15\%) & $20 \sim 25 \mathrm{~g} / \mathrm{Nm}^{3}$ & $0.03 \sim 0.05 \mathrm{~g} / \mathrm{Nm}^{3}$ & 電気集じん+湿式脱硫 \\
\hline
\end{tabular}

（注）（1）窒素酸化物の発生濃度は燃焼改善効果を含む。

(2) $\eta$ は除去効率を意味する。

（3）窒素酸化物についての処理後の濃度は，発生濃度が $300 \mathrm{ppm}$ の場合に脱硝装置 を導入した例を掲載した。

（4）脱硫，除じん装置は全計画において設置されるが，窒素酸化物の処理は，二段燃 焼，排ガス混合等燃焼改善だけで対策する例も多い。

表 119 電力会社発電用燃料消費実績

\begin{tabular}{|c|c|c|c|c|c|c|c|c|c|c|c|}
\hline \multirow{2}{*}{ 項 } & \multirow{2}{*}{ 目 } & \multirow{2}{*}{ 単 位 } & \multicolumn{3}{|c|}{52 年度実 樍 } & \multicolumn{3}{|c|}{53 年度実 績 } & \multicolumn{3}{|c|}{54 年度実 績 } \\
\hline & & & 数 量 & 硫黄分 & $(\%)$ & 数 量 & 硫黄分 & $(\%)$ & 数 & 硫黄分 & $(\%)$ \\
\hline \multicolumn{2}{|c|}{ 汽力発電電力量 } & 億 $\mathrm{kWh}$ & 2,948 & & - & 2,935 & & - & 2,977 & & - \\
\hline \multicolumn{2}{|c|}{ 総合重油換算量 } & 万 $\mathrm{k} l$ & 6,854 & $(0.24)$ & 0.45 & 6,826 & $(0.20)$ & 0.44 & 6,923 & $(0.20)$ & 0.43 \\
\hline 石 & 炭 & 万 $\mathrm{t}$ & 437 & & 0.55 & 413 & & 0.56 & 443 & & 0.56 \\
\hline 重 & 油 & 万 $\mathrm{k} l$ & 3,061 & & 0.80 & 2,892 & & 0.84 & 2,853 & & 0.87 \\
\hline 原 & 油 & 万 $\mathrm{k} l$ & 2,273 & & 0.16 & 2,139 & & 0.14 & 1,853 & & 0.14 \\
\hline ナ & & 万 $\mathrm{k} l$ & 379 & & 0.05 & 237 & & 0.05 & 233 & & 0.05 \\
\hline $\mathrm{N}$ & $\mathrm{L}$ & 万 $\mathrm{k} l$ & 294 & & 0.06 & 332 & & 0.05 & 292 & & 0.05 \\
\hline $\mathrm{L}$ & & 万 t & 556 & & 0 & 794 & & 0 & 1,101 & & 0 \\
\hline $\mathrm{L}$ & G & 万 $\mathrm{t}$ & 4 & & 0 & 33 & & 0 & 57 & & 0 \\
\hline 天 & j & 億 $\mathrm{Nm}^{3}$ & 6.6 & & 0 & 6.5 & & 0 & 6.1 & & 0 \\
\hline コー & あガス & 億 $\mathrm{Nm}^{3}$ & 4.8 & & 0.15 & 5.7 & & 0.16 & 6.1 & & 0.16 \\
\hline
\end{tabular}

(注) 硫黄分欄の（）内の数值は排煙脱硫後の值である。

（出典） 通産省電力需給の概要昭和 $53,54,55$ 年度版より作成

4.3.1.3 ばいじん

石炭火力における除じんは専ら電気集じん機を使い, 99\%以上のばいじんを除去するとともに，湿式脱硫装 置によって微細粒子を除去している。石油火力におけ るばいじん排出濃度は $0.01 \sim 0.03 \mathrm{~g} / \mathrm{Nm}^{3}$ であるのに 対して, 石炭火力ボイラーの場合は $0.03 \sim 0.05 \mathrm{~g} / \mathrm{Nm}^{3}$ が計画值なので，排出量は 2 倍以上になる場合が多い。 石炭ボイラーのばいじん濃度を更に低減する方法と
しては,バグフィルターか湿式除じん装置を追加する ことが考えられる。

\subsection{2 低減対策の現状と開発動向}

4.3.2.1 SO $x$ 低減対策

環境大気中への $\mathrm{SO}_{\mathbf{x}}$ 低减対策は，燃焼前と燃焼中 および燃焼後の 3 つに大別される。これらの方法を整 理したのが表 12 である。

1）燃䓎前の対策 
1)-1 低硫黄炭の確保

石炭中の硫黄含有率は, 同一の炭層から採掘した石 炭でも，炭層の上盤及び下盤ぎわにある石炭に高い傾 向があるなど石炭中の $\mathrm{S}$ 含有率を決定する要素は単純 ではない。

海外一般炭の利用には, 流通システムの未整備など 問題が多いため, 低硫黄炭を安定的に確保することは むずかしいことであり, 石油利用の場合と違う点でも ある。

$$
\text { 1) }-2 \text { コールクリーニング }
$$

コールクリーニングとは, 石炭としての質を本質的 にこわすことなく，燃焼などの利用技術によって污染 物質となるミネラル, 硫黄などを物理的, または化学
表 12 石炭利用における硫黄酸化物低減対策の分類

\begin{tabular}{|c|c|}
\hline & 対 \\
\hline 燃 焼 前 & $\begin{array}{l}\text { 低硫黄炭の確保 } \\
\text { コールクリーニング }\end{array}$ \\
\hline 燃 焼 中 & $\begin{array}{l}\text { セメントキルンにおける脱硫効果 } \\
\text { 流動床燃焼における脱硫効果 }\end{array}$ \\
\hline 燃 焼 後 & $\begin{array}{l}\text { 排煙脱硫 } \square \text { 湿式脱 硫 } \\
\text { 乾式脱 硫 }\end{array}$ \\
\hline
\end{tabular}

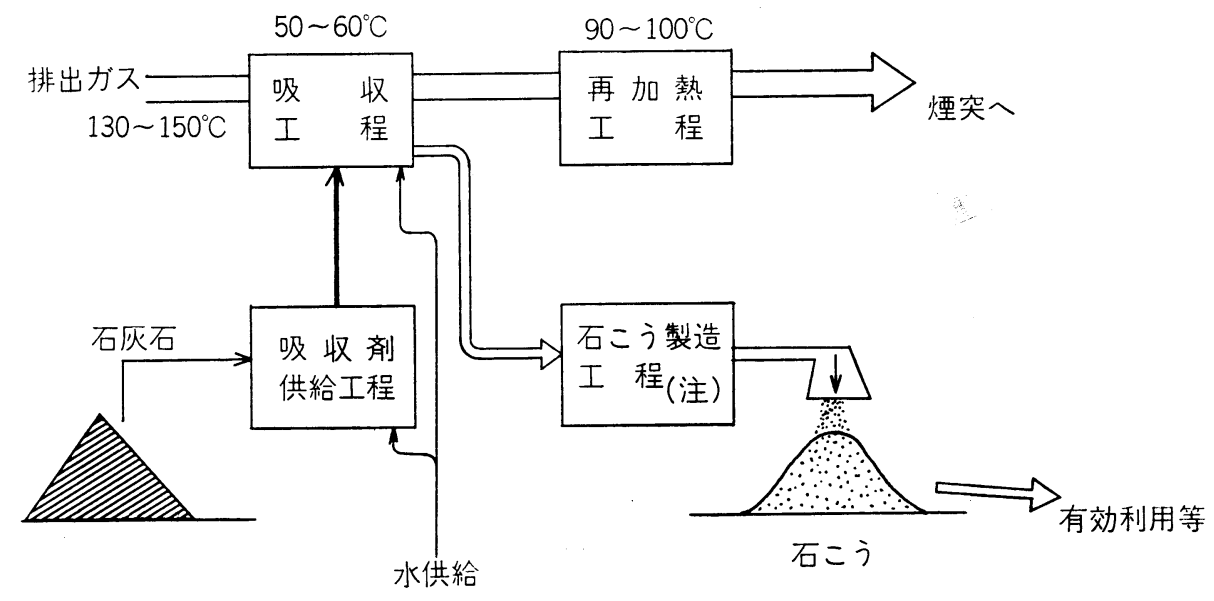

（注）脱水，污泥除去工程含む

図 2 湿式石灰石 - 石こ 5法概略図

的に除去する技術である。

物理的方法では, 比重やぬれ，または磁性などの物 理的な性質を利用して無機硫黄分 $\left(\mathrm{FeS}_{2}\right)$ を処理する やり方である。これに対して化学的方法は, パイライ 卜硫黄の多い石炭を脱硫処理するものであり, 具体的 には空気または酸素による酸化処理法や, 硫酸第二鉄 水溶液による溶出法などがある。

しかし，今のところいずれの方法も実用化の段階に 至っていないが, コールクリーニングは $\mathrm{NO}_{\mathbf{x}}$ 対策と しても有効な方法であると見られている。

\section{2）燃焼中の対策}

流動床燃焼の場合, 媒体として石灰石 $\left(\mathrm{CaCO}_{3}\right)$ や ドロマイト $\left(\mathrm{CaCO}_{3} \cdot \mathrm{MgCO}_{3}\right)$ を用いて, 燃焼温度を $850^{\circ} \mathrm{C}, \mathrm{Ca} / \mathrm{S}$ を 4 で燃焼させると, $90 \%$ の脱硫効 果があるとされている。また, 流動床燃焼では, 微粉
炭燃焼方式に比較して，炭種の制限を受けないこと， 粗粉炭でも使えること，また燃焼温度が低いためにサ 一マル $\mathrm{NO}_{\mathbf{x}}$ の抑制になるなどの利点がある。

こうしたことから，流動床燃焼方式は公害防止技術 の新しい分野でもあり, 環境保全面から期待されてい る。

3）燃焼後の対策

石炭利用の場合における排煙脱硫法としては, もっ ぱら湿式の石灰一石こう法が採用されている。

吸収剂としてスラリー状の石灰石を用い, 石こうを副 生する方法で, その概要を示したのが図 2 である。

湿式脱硫法は，少なくとも $90 \%$ の脱硫効果が期待 できるものの, 石炭火力に採用した場合, 次の点に留 意する必要がある。

（1）高浱度の $\mathrm{SO}_{\mathrm{x}}$ 含む排ガスを処理する場合，ス 


鈴卓

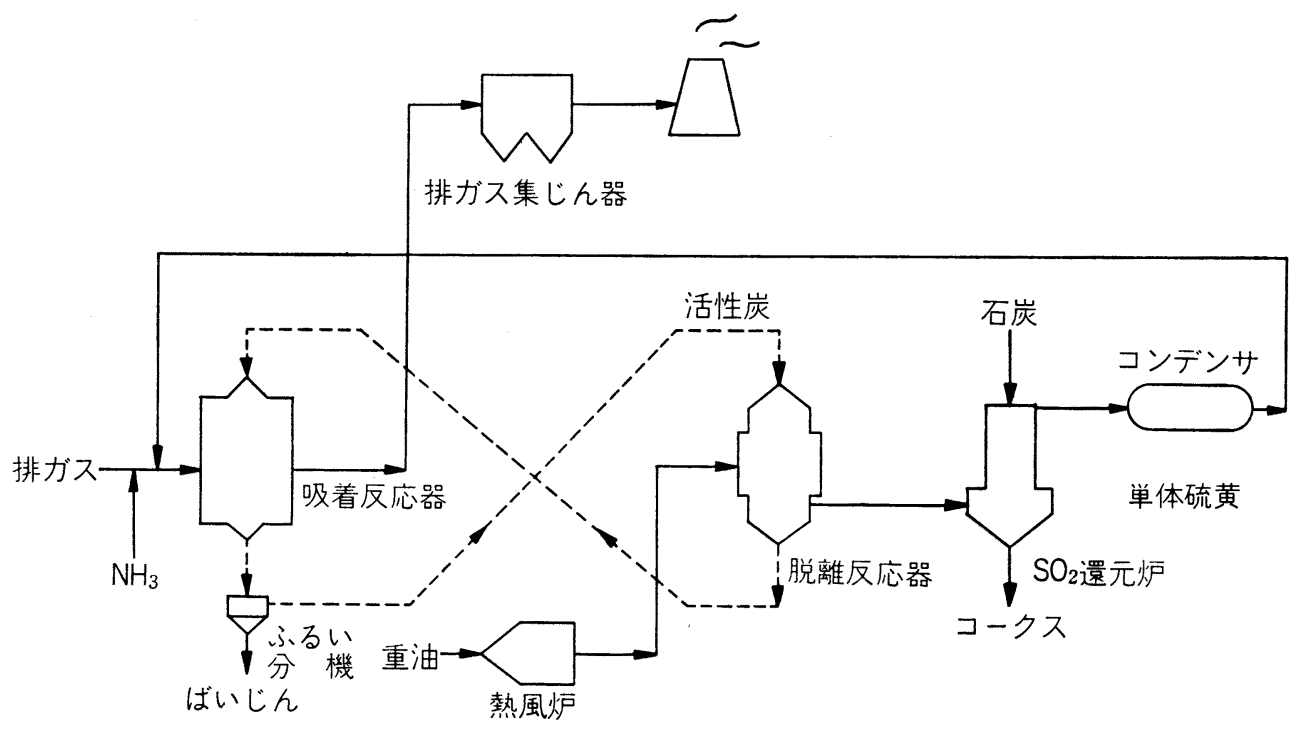

（出典）石炭利用に伴ら大気污染に係わる情報収集調查, 1980.3 環境惢委託事業

図 3 乾式脱硫装置全体フロー図

表 13 石炭利用における窒素酸化物低減対策の分類

\begin{tabular}{|c|c|c|c|c|}
\hline & & & $\begin{array}{l}\text { フュエル } \\
\text { Fuel } \\
\mathrm{NO}_{\mathbf{x}}\end{array}$ 対策 & $\begin{array}{l}\text { サーマル } \\
\text { Thermal } \mathrm{NO}_{\mathbf{x}} \text { 対策 }\end{array}$ \\
\hline 燃 & 焼 & 前 & 低坌素䈐の確 保 & $\begin{array}{l}\text { コールクリーニングによ } \\
\text { る脱灰に伴う効果 }\end{array}$ \\
\hline & & 中 & \multicolumn{2}{|c|}{ 燃 焼 改善 $\left[\begin{array}{l}\text { 低 } \mathrm{NO}_{\mathrm{x}} \text { バーナ } \\
\text { 二 段 燃 焼 } \\
\text { —排ガス再循環等 }\end{array}\right.$} \\
\hline 燃 & 焼 & 後 & 排煙脱硝装置（乾王 & \\
\hline
\end{tabular}

ケールが付着して運転に支障を来たすことがある。

(2) 石炭に含まれるフッ素は, 燃焼によってフッ化 水素となり, 石灭石と反応して $\mathrm{CaF}_{2}$ を形成し, 脱硫 率を低下させる要因となるばかりか, 石こうの品質に も悪影響がある。

(3) 脱硫装置から発生する排水の処理問題がある。

こうした点をカバーするため, 活性炭を利用する乾 式脱硫方式の開発が進められている（図 3)。

\subsubsection{NOx 低減対策}

石炭利用における $\mathrm{NO}_{\mathbf{x}}$ の低減対策をまとめると，
表 13 のよらになる。

1）燃焼前の対策

石炭は石油に比べて一般的にN含有率が高く,これ に伴ってフュエル $\mathrm{NO}_{\mathbf{x}}$ の発生量が多い。過去の実績

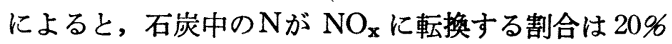
程度であるといわれている。

しかし, 実際にN分の少ない石炭を安定確保するこ とは至難であるといわざるを得ないであろう。

2）燃焼中の対策

(1) 燃焼改善 
これは, 火炎温度の低減, 空燃比の抑制, 高温雾囲 気での滞留時間の短縮等を基本原理とし, 具体的な方 法としては火炉冷却面積の増加, 燃焼用空気温度の低 下，排ガス，水などのバーナー部への注入，二段燃焼 及びバーナー部における空気比の抑制などがある。

一般的には，これらの低 $\mathrm{NO}_{\mathbf{x}}$ 技術をいくつか組み 合わせて対応するが，実用化の目途がついている然烓 改善技術によって達成できる $\mathrm{NO}_{\mathrm{x}}$ 排出濃度は, 微粉 炭ボイラーの場合で 170 180 ppm とされている。

(2) 流動床燃焼

このタイプの ボイラーは，燃焼温度が低い（750～ $\left.900^{\circ} \mathrm{C}\right)$ ので，サーマル $\mathrm{NO}_{\mathrm{x}}$ の抑制ができること， また流動床に石灰石を用いると副次的に $\mathrm{NO}_{\mathbf{x}}$ が抑制 されるなどの特徴をもっている。

これは, $\mathrm{CO}$ などの䢱元性ガスによって, NO が分 解されて $\mathrm{N}_{2}$ になること, また未燃カーボンによって NO が分解されるものと推定されている。

$$
\begin{aligned}
& \mathrm{NO}+\mathrm{CO} \longrightarrow 1 / 2 \mathrm{~N}_{2}+\mathrm{CO}_{2} \\
& 2 \mathrm{NO}+\mathrm{C} \longrightarrow \mathrm{N}_{2}+\mathrm{CO}_{2} \\
& \mathrm{NO}+\mathrm{C} \longrightarrow 1 / 2 \mathrm{~N}_{2}+\mathrm{CO}
\end{aligned}
$$

\section{3）燃烵後の対策}

見在実用化されている排煙脱硝装置は，もっぱら乾 式のアンモニア接触還元法である。

クリーン排ガスの脱硝処理は特に問題ないが，いわ ゆるダーティ排ガスの処理では触媒劣化を起こすとい う技術的な制約があった。

しかし，これらのダーティ排ガスの处理もできる脱 硝技術に関する開発が続けられた 結果，55 年秋には 石炭火力発電所にも適用されるよらになってきている。 石炭専焼火力に導入する場合, 最も問題となるのは排 ガス中に含まれるダストによる妨害である。この対策 としては，低ダスト方式と高ダスト方式とがあるが，

電気集じん装置による除じんむおこなわれている。

\subsubsection{3 総合排煙処理システム}

排煙処理技術については, 個別のばい煙処理技術を 組み合わせ， 2 種類以上の污染物質を除去しょうとす る場合は, 処理装置が相互に及ぼす影響や処理温度条 件等を考慮して, 適正化を図ることが必要である。

排煙処理装置における相互影響をまとめたのが表 14 である。

現在まで計画されているか, 検討されている総合処 理システムと，その結果得られる対策レベルを示した のが図 4 である。

\subsubsection{4 粉しん}

これは石炭利用に伴ら固有の問題である。粉じんの 発生過程として最も重要なものは, 眝炭場からの炭じ
ん発生であるが，この対策としては散水方式と防風ネ ット等が用いられている。

しかし, 散水と防風ネット等の効果だけでは充分な 炭じん対策とはならない場合もあり, 屋内貯炭方式や サイロ貯炭方式を導入する例もある。

\subsubsection{5 の 他}

微量金属, 多環芳香族炭化水素および八ロゲン（フ ッ素, 塩素）による大気污染問題もあるが, これにつ いては説明を割愛する。

\section{4 水質污濁に関する問題}

\subsection{1 貯炭場の排水による水質污濁}

主として $\mathrm{pH}$ の低下と SS が問題になるが，SSにつ いては $1,500 \sim 1,600 \mathrm{mg} / \mathrm{l}$ になることもあるとされて いる。

この対策としては, 充分な容量のタンクを設けると ともに, 中和, 沈貶処理用の設備が必要である。

\subsection{2 脱硫排水による水質污濁}

湿式脱硫装置からの排水量は, 100 万 $\mathrm{kW}$ の石炭火 力を例にとると, 最大 $1,000 \mathrm{~m}^{3} /$ 日にも達し, 発電所 全体（温排水除く）の $2 / 3$ にあたる排水量である。

脱硫排水は, 排ガス中のばいじんあるいはガス成分 を含んでおり, $\mathrm{COD}$, 塩素, $\mathrm{pH}$ 等について適切な対 忘が必要である。

\section{5 産業廃棄物の処理に関する問題}

石炭利用に伴ら環境保全として, 産業廃棄物の処理 問題は, 大気污染とならんで重要である。石炭に含ま れる 15 20\% の灰分は, 石炭灰として発生すること になる(鉄鋼業では高炬スラグ)。

これらを有効利用することは, 環境保全上最も好ま しいことであるが，埋立て処分する例が多く大規模な 土地の確保難が大きな問題となっている。

海面の埋立てによって処分する場合には, 自然海浜 の消减および藻場, 干潟の消滅等による陸上, 水生生 物への影響等が懸念される。こうした環境保全上の問 題は, きわめて総合的であるらえ, 個別の公害規制の みでは適切な対応ができないなど行政対応自体に困難 な面を含んでいる。

\subsection{1 石炭灰処理の現状}

石炭火力発電所から発生する石炭灰の処理状況をみ ると (53 年度), 次の通りである。

石炭灰の発生量は 205 万 $\mathrm{t}$ で, 北海渞と山陽地方に おける発生量が大きく, 各々 123 万 t , 44 万 t とな っている。このうち有効利用量は 54 万 $\mathrm{t}$ 程度であり, 利用率は石炭灰発生量の $26.2 \%$ になっている。有効 利用の 内訳は, セメント原材料として 44 万 $\mathrm{t}$ 余で大 半を占め, そのほか土壌改良剤として $3,000 \mathrm{t}$, 坑道 


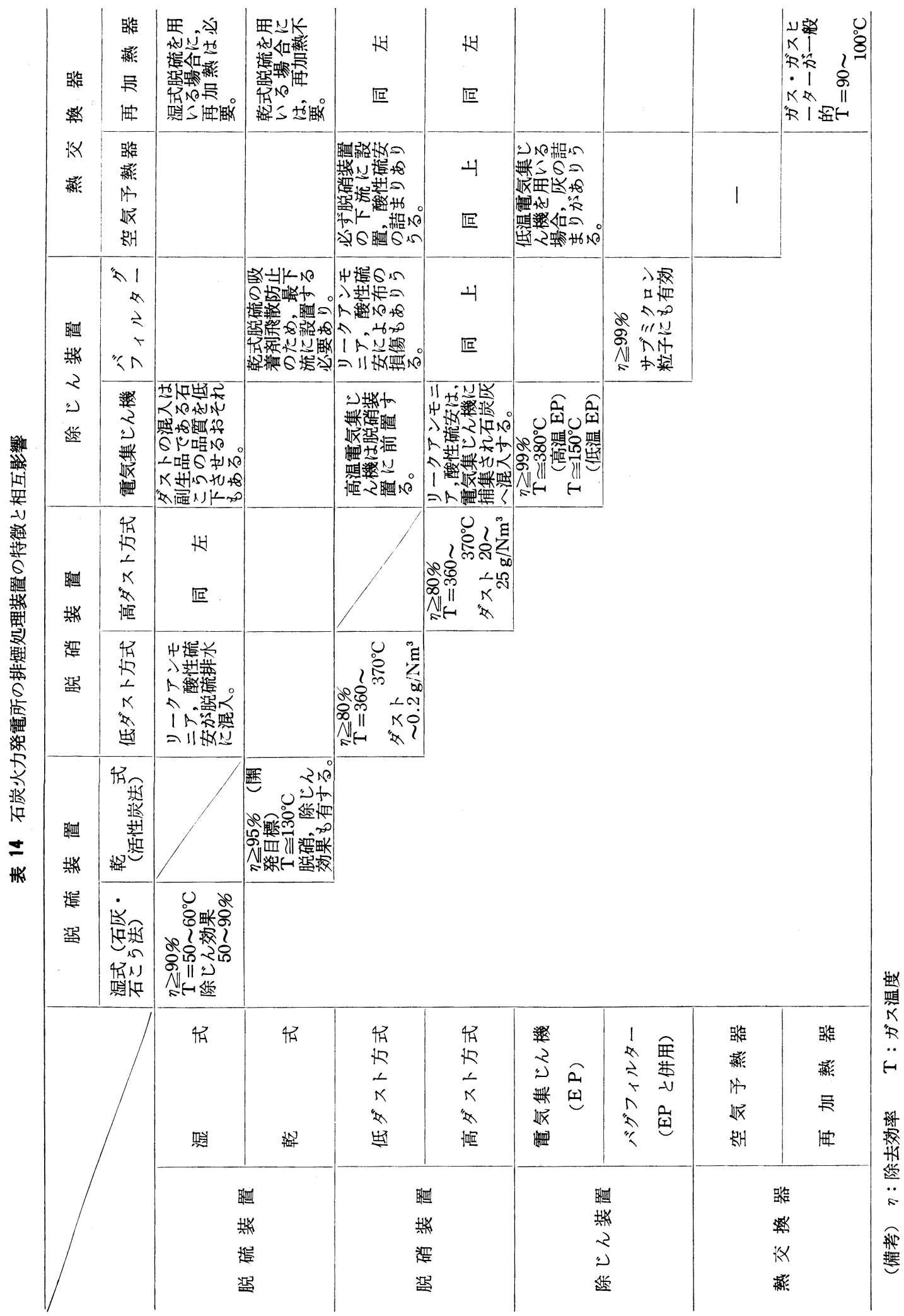




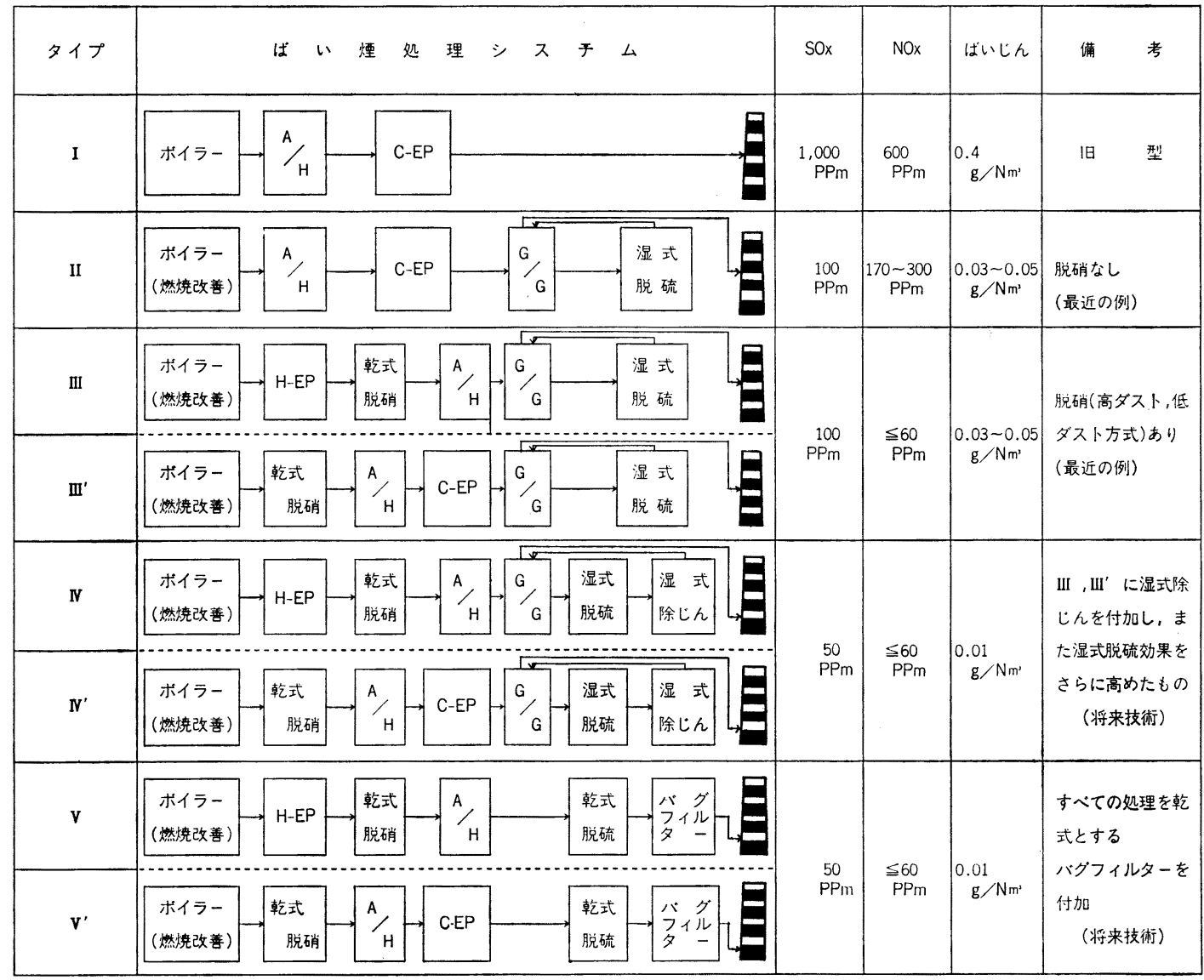

（注） C-E P 低温電気集じん機 $\mathrm{H}-\mathrm{E} \mathrm{P}$ 高温 " $\mathrm{A} / \mathrm{H}$ 空気予熱器
$\mathrm{G} / \mathrm{G}$ 再加熱器

硫黄含有率 $1.2 \%$

窒素含有率 $1.8 \%$

図 4 石炭火力発電所の排煙処理システム（例）

閉鎖などに $9,000 \mathrm{t}$ となっている。 有効利用されない 150 万 $\mathrm{t}$ 余の石炭灰は, すべて埋 立て処分されており，海洋への投入は行われていない。 埋立て処分地はほとんど陸上であるが, 内水面や海面 で埋立処分をおこなっている例もある。

今後建設が予定されている石炭火力発電所の扊処理 計画では，ほとんどが海面埋立を予定しており，多く は全量埋立てした場合の $7 \sim 8$ 年分を確保している。

4.5.2 石炭灰の有効利用技術

現在の有効利用技術（未完成のものも含む）につい ては表 15 に示したが，このなかで技術的に確立して おり，しかも利用量の大きいのはセメント混和剤であ る。さらに今後の利用分野として注目されるのは, 農 業関係（ケイ酸カリ肥料として）と道路工事用路盤材
としての利用である。

\section{6 そ 他}

石炭の利用に伴う環境影響として留意すべき点とし ては, 大型港湾設備の構築に伴う自然環境の改変や湿 式脱硫装置に使う用水の取得，さらには石炭の搬送設 備と砕炭機等による騒音, 振動問題への対応が必要で ある。

\section{5. 石炭利用の拡大に関する環境保全上の課題}

今後の利用挔大は, 電気事業を中心としてセメント, 紙・パルプ, 化学工業等で進むことが見込まれる。石 炭火力の 規模は， 65 年度末に 3,000 万 $\mathrm{kW}$ 近くにな るとされており，またセメント業においても転換の速 度は予想以上に急速である。 
表 15 石炭灰の有効利用技術等について

\begin{tabular}{|c|c|c|c|c|c|}
\hline 有効利用分野 & 対象となる灰 & $\begin{array}{l}\text { 技術等 } \\
\text { の熱度 }\end{array}$ & 実績 & 加工度 & 技術上の特徴と問題点等 \\
\hline セメント混和材 & $\begin{array}{l}\text { フライアッシュ } \\
\text { (微 粉) }\end{array}$ & (9) & 大 & 一次 & 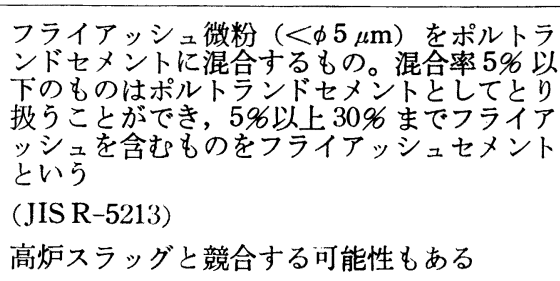 \\
\hline セメント原料 & $\begin{array}{l}\text { フライアッシュ } \\
\text { シンダーアッシッ } \\
\text { クリンカー }\end{array}$ & 0 & 中 & 一次 & $\begin{array}{l}\text { セメント原料の } 18 \% \text { を占める粘土の } 10 \sim 20 \\
\text { \%を石炭で代替するもの } \\
\text { 技術上決定的な問題はない } \\
\text { 粘土のコストを下回れば，利用扰大の可能性 } \\
\text { あり }\end{array}$ \\
\hline コンクリート骨材 & $\begin{array}{l}\text { フライアッシュ } \\
\text { (粗) 粉) } \\
\text { クリンカー }\end{array}$ & 0 & 小 & 一次 & $\begin{array}{l}\text { コンクリート骨材の細砂に代替するもの } \\
\text { 砂の採取が困難になったとき, 有力な代替材 } \\
\text { となる。 }\end{array}$ \\
\hline 人工軽量骨材 & $\begin{array}{l}\text { フライアッシュ } \\
\text { (粗 粉) } \\
\text { クリンー }\end{array}$ & 0 & 小 & 二次 & $\begin{array}{l}\text { コンクリート骨材の砂利に代替するもの } \\
\text { 頁岩あるいは粘土と共に } 1,000 \sim 1,200^{\circ} \mathrm{C} \text { で } \\
\text { 焼成する } \\
\text { 焼成加工コスト低減のため廃熱利用等が必要 }\end{array}$ \\
\hline 路 盤 材 & $\begin{array}{l}\text { フライア粗 } \\
\end{array}$ & O & 小 & 一次 & $2 \sim 3$ 年放置したフライアッシュ粗粉を使用 \\
\hline 礁 & $\begin{array}{l}\text { シンダーアッシュ } \\
\text { フライアッシュ }\end{array}$ & $\Delta$ & 小 & 二次 & $\begin{array}{l}\text { シンダーアッシュ,フライアッシュを有機系 } \\
\text { 接着剤で固めたもの } \\
\text { コスト的には引き合らとみられる }\end{array}$ \\
\hline $\begin{array}{l}\text { 肥 料 } \\
\text { (理酸カリ肥料) }\end{array}$ & フライアッシュ & O & 小 & 二次 & 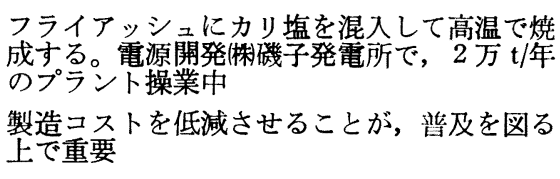 \\
\hline 断 熱 建 材 & フライアッシュ等 & $\triangle$ & 小 & 高次 & $\begin{array}{l}\text { セメント二次製品用の原料として, ボード・ } \\
\text { パネル等を生産する } \\
\text { 徤材の多樣性から石炭灰のほとんどが利用可 } \\
\text { 能と見られる }\end{array}$ \\
\hline $\begin{array}{llr}\text { 無 } & \text { メ } & \text { ト } \\
\text { 硬 } & \text { 化 } & \text { 材 }\end{array}$ & $\begin{array}{l}\text { フライアッシュ } \\
\text { シンダーアッシュ } \\
\text { クリンカ- }\end{array}$ & $\Delta$ & 小 & 二次 & 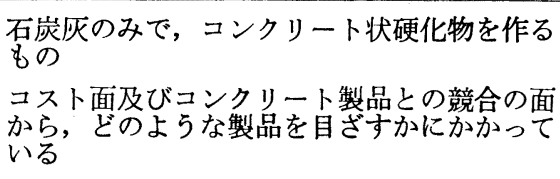 \\
\hline
\end{tabular}

（注）技術等の熱度 ○ 利用技術, 需要面とも完成しているもの

○利用技術は目途がついているが需要上の問題等が残っているもの

$\Delta$ 利用技術について研究・開発中のもの

奏 績 大 利用実績が 10 万 $\mathrm{t} /$ 年以上のもの

中 " $1 \sim 10$ 万 $\mathrm{t} /$ 年のもの

小 " 1 万 $\mathrm{t} /$ 年以下のもの 
このような状況のもとで，今後，関係行政機関およ び石炭を利用する事業者は, 環境保全のためにとるべ き措置と対策を各々の責務として検討しなければなら ないが，その際に基本とすべき方針と検討すべき課題 について提示されたものである。

\section{1 石炭利用施設等の立地点を選定する際の留意 事項}

\section{1 .1 大気環境保全に関する事項}

石炭ボイラーは，一般にばい煙排出量が大きく，ま た眝炭場からの粉じん飛散も生ずることから, 江地点 の選定にあたっては，当該地域における大気の環境保 全に支障を与えない上うに，充分な検討が必要である。

特に, 大気污染に係る環境基準をこえている地域お よび超える恐れのある地域にあっては，現在および将 来に㧍ける大気污染の推移を見通した上で，地域環境 の保全計画ならびに石炭ボイラー等の大気污染防止対 策によって, 環境基準の維持, 達成が可能であること の根拠を示して立地上の前提にすべきである。

\section{1 .2 瀬戸内海沿岸における立地に関する事項}

瀬戸内海における埋立は厳に抑制すべきであるとさ れていることから，公有水面の新規埋立を伴う石炭利 用施設および関連施設の立地については，基本的に避 けるべきである。

\section{1 .3 自然環境保全に関する事項}

石炭利用のための施設は，一般的に自然改変の程度 が大きいと考えられることから，自然環境の保全にも 充分配虑する必要がある。

\section{2 石炭利用施設の理境保全対策}

\subsection{1 大気活染防止対策}

石炭ボイラーの新設に当たっては，ばい煙の排出レ ベルを石油ボイラーと同程度とすることを目途とし, また，既設での石炭転換もしくは石炭の焚增し計画に あっては, 計画実施後のばい煙量が計画実施前のそれ を上回らないことを目途とし，当該地域における大気 污染の実情に応じて適切な大気污染防止対策を講ずべ きである。

さらに，粉じんの防止対策についても充分な対応が 肝要である。

\section{2 .2 石炭灰の処理等}

石炭灰は管理型の廃棄物であることから，埋立処分 にあたっては廃棄物処理法に基ゔく処分基準，処分場 の構造基準, 維持管理基準を満たすべきことは当然で あるが，処分地の確保難という観点からもできるだけ 有効利用を図るよう努力すべきである。

なお，地方公共団体においては，石炭利用の搪大を 見込んで予め地域の諸条件を考慮し，石炭灰の処理， 処分および有効利用に関する基本方針を定め，それに 沿って事業者を指導することも有用な行政手段であろ う。

\section{3 今後さらに検討すべき事項}

石炭利用に係る環境影響評価を一層充実させるため, 次の措置を講ずることが望ましい。

1）石炭利用施設に対する環境保全技術の開発およ び石炭灰の有効利用技術に関する開発と利用分野の開 拓を推進すること。

2）新しい石炭利用技術の開発，実用化にあたり， 環境影響の面からの評価も併せて行うこと。

3）事業者においては, 使用する石炭の質および環 境への污染物質排出状況等について常に把握しておく こと。

\section{6. おわりに}

以上，今後のエネルギーと環境問題に関する提言な らびに石炭利用の拡大に伴う環境問題とその対策につ いての検討リポートから，その要点を紹介した。

また, 当業界における石炭転換計画についても触れ たが，これを計画通り推進するためには多くの問題点 をかかえており, 特に今後の環境行政のあり方と, 海 外炭の受入体制がキーポイントになるものと考えられ る。

エネルギーか環境かといら二者択一ではなく，これ をどのように両立させるかが最も重要な点である。

当業界としても, 石炭火力発電所における環境保全 対策ならびに石炭灰の有効利用等について大いに学ぶ と同時に，今後の技術開発と環境行政の動向に注目し， 時宜適切な対応をして行く必要があると考えている。 